\title{
A Perception Based Analysis of Internationalization at Malaysian Private Universities
}

\author{
Santhi Ramanathan \\ Faculty of Business and Law \\ Multimedia University, Malaysia \\ E-mail: santhiramanath@gmail.com \\ Seethaletchumy Thambiah \\ Faculty of Management \\ Multimedia University, Malaysia \\ E-mail: seethaletchumy@mmu.edu.my \\ Kavitha Raman \\ Faculty of Business and Law \\ Multimedia University, Malaysia \\ E-mail: kavitha.raman@mmu.edu.my
}

Received: November 4, 2011

Accepted: December 6, $2011 \quad$ Published: February 16, 2012

doi:10.5539/ijbm.v7n4p13

URL: http://dx.doi.org/10.5539/ijbm.v7n4p13

\begin{abstract}
The purpose of this paper is to examine whether the Malaysian private universities' international efforts adhere to the general approach to internationalization and to explore the degree of perceived importance and perceived implementation those efforts at institutional level. By integrating several models and frameworks proposed by scholars in internationalization domain such as Knight and Zha, the paper presents a conceptual framework comprising preliminary factors, strategy factors and process factors of internationalization at universities. Instrument developed for these factors were tested on 204 academics from 10 Malaysian private universities to analyze their perceived importance and perceived implementation. Based on an overview of all factors, it is found that the average mean values of factors that perceived as important are higher than the values accounted for the perceived degree of implementation of internationalization at Malaysian private universities. The study extends the scope of the internationalization literature on an emerging market context and probably one of the first to conduct empirical tests/structured questionnaire in assessing internationalization issues in the context of the Malaysian private university sector. The study traced internationalization efforts of Malaysian private universities which provide practitioners with more evidence of the value of internationalization. The conceptual framework exemplified in this study is considered the most significant contribution of this research work in terms of providing measurement tools for evaluation and assessment of internationalization efforts in the higher education domain.
\end{abstract}

Keywords: Internationalization, Private universities, Malaysia

\section{Introduction}

Globalization and internationalization have changed the structure of higher education system worldwide. International activities of most universities in terms of international students' recruitment, faculty mobility, twinning programs, foreign branch campuses have expended tremendously. Internationalization has gained the attention of many scholars (Knight, 2004, 2006; Zha, 2003; Bartell, 2003; Marginson, 2004, 2006; Altbach and Knight, 2006; Mok, 2007; Ayoubi and Massoud, 2007; Ahmad S, 2007; Chan and Dimmock, 2008; Childress, 2009) and international organizations such as UNESCO, World Bank, OECD and UNDP.

Internationalization simply means that the practices or processes of an activity in one nation is being mixed up 
with those from other parts of the world as this process may perhaps be a device towards an individual's, organization's or a country's goal achievement. The concept of internationalization of higher education seems to cover a wide range of methods and approaches. Although the approaches of internationalization appear in multiple forms (Zha, 2003; Irene, 2003; Knight, 2004; Ayoubu and Massoud, 2007) and different across authors, most studies have reflected the term internationalization using almost similar key words or phrases. Knight (1997) defines internationalization as the process of integrating an international and intercultural dimension into the teaching, research and service of an institution. As the future of higher education is neither simple nor straightforward (Altbach \& Peterson, 1999), many scholars in the $21^{\text {st }}$ century have discovered the need to construct a broader or generalized definition of internationalization. Consequently, Knight (2004) introduced a new definition of internationalization in accordance to the need to ensure that the definition does not specify the rationales, benefits, outcomes, actors, activities, and stakeholders of internationalization, as they vary enormously across nations and also from institution to institution. Knight defined internationalization as the process of integrating an international, intercultural or global dimension into the purpose, functions or delivery of post-secondary education. Zha (2003) has described internationalization as one of the ways a country responds to the impact of globalization, yet at the same time respects the individuality of the nation. Bartell (2003) referred to internationalization as an organizational adaptation which requires its articulation by the leadership while simultaneously institutionalizing a strategic planning process that is representative and participative in that it recognizes and utilizes the power of the culture within which it occurs.

Many countries perceived internationalization as crucial in achieving international academic standards (Knight, 2004). As for many universities in developed countries, internationalizing their campuses can help students acquire knowledge, skills, and experiences to be able to compete in the global economy and become productive members of a diverse world society (Bendriss, 2007). This rationale is found to have an impact on institutional assessment systems at the international as well as at the national level (Jang, 2009). The vast adaptation of internationalization among higher education providers world-wide triggered by globalization and the lack of uniformity in terms of ranking systems have caused many institutions of higher learning across the globe to claim either that they have the plan to become a world-class university by a certain date or that they have already achieved this status (Birnbaum, 2007). In this juncture, the issue of the absence of a comprehensive set of indicators and data sources for evaluating the extent of an institution's internationalization is always the primary obstacle for researchers (Haywards, 2000 cited in Horn et al, 2007). Internationalization of higher education models developed by Zha (2003), Knight (2004), Ayoubi \& Massoud (2007) and Horn et al (2007) have contributed wide knowledge to many scholars as well as recommendations to further extend the existing frameworks and methodologies to be applicable in an emerging market context. The great diversity of contexts, perceptions, rationales and priorities affecting institutional views and practices tend to limit those models in examining the perceived importance and the level of implementation of internationalization at the institutional level in different contexts (Courts, 2004; Childress, 2009).

As for developing countries including Malaysia, internationalization has changed the landscape of higher education system in terms of student and faculty composition, program and curriculum mobility and the diversity of higher education providers (Ziguras, 2001; Mok, 2007; Morshidi, 2007; Yonezawa, 2007; Akiba, 2008; Tham \& Kham, 2009). In the context of Malaysian higher education, there are six pertinent issues to be addressed pertaining to internationalization efforts.

1) There is a greater demand to address the issue of the absence of a unified cum transparent performance assessment system for the whole university sector (World Bank, 2007).

2) Currently private universities in Malaysia holds a bigger portion of higher education sector (MOHE, 2008) and thus their efficiency in integrating the internationalization dimension has a greater impact on the nation's endeavor to become a regional hub of education.

3) However, there is lack of exposure and participation of local private universities in local (Malaysian Business, January, 2003; The Star Education, June, 2008), Asian or world rankings.

4) There is no exclusive model or framework provided as to guide the private university sector, which is a fairly new and competitive sector (Malaysian Business, January, 2003), largely driven by global needs (UNESCO: Gill, 2005) and will probably remain the main site for growth in international education (OECD: Marginson \& McBurnie, 2004; Akiba, 2008).

5) Thus, there is also a greater demand to address the issue of the internationalization performance assessment especially in the emerging private university sector (Tan, 2002; Sivalingam, 2006; Akiba, 2008; Ramanathan and Halimah, 2009; Ramanathan and Raman, 2009; MOHE, 2007-2009). 
6) The scope of the internationalization-performance assessment literature needs to be extended with a more empirical investigation with appropriate indicators particularly to be applicable in the emerging private university sector.

This study is an attempt to contribute, given these gaps in the body of the internationalization of higher education literature, focusing specifically on Malaysian private universities (MPUs) by examining whether the international efforts adhere to the general approach to internationalization at the institutional level based on the framework comprises the preliminary internal and external policy factors, strategies factors, and process factors of internationalization. Secondly is to explore the perceived level of importance and the perceived degree of implementation of internationalization factors at institutional level.

Based on the review of literature (Fielden, 1996; Elango, 1998; Manning, 1998; Bourke, 2000; Welle-Strand, 2002; Irene, 2003; Anderson, 2004; Courts, 2004; Enders, 2004; Knight, 2004; Navarro, 2004; Reedstrom, 2005; Thune and Welle-Strand, 2005; Ahmad, 2007; Bentkowska, 2007; Weerawardena et al, 2007; Welch, 2007; Casillas et al, 2008; Kafouros et al, 2008; Tuppura et al, 2008; Wang et al, 2008; Brennan and Garvey, 2009; Dewey and Duff, 2009; Horta, 2009; Zeng et al, 2009; Radakrishnan and Ramanathan, 2010) there are many factors that have been identified as contributing towards successful or progressive internationalization. These factors seem to fall across various groups or categories such as preliminary policies, strategies and processes as exemplified by the conceptual framework shown in Figure 1.

\section{Methodology}

A survey questionnaire was administered to investigate the perception of faculty in private universities in Malaysia on the general aspects such as their personal details and institution's demographic characteristics as well as specific issues on internationalization efforts perceived as important and implemented in the respondent's institution. This study adopted a three stage sampling strategy or technique proposed by Mohayidin et al (2007). In the first stage, all the degree-awarding private universities in Peninsular Malaysia with either a university or university college status were selected. Since the presence of international students and scholars is an important indicator of an internationalized campus (Irene, 2003), the institutions selected for current study were all having international students and staff on campus. The above criteria were developed for sampling selection to ensure the set of universities and respondents are comparable to each other. Based on the list of local private universities consisted of 36 institutions as of 2008 produced by the Malaysian Ministry of Higher Education (MOHE), 30 universities were found to have the criteria developed for sample selection in current study. From 22 institutions which had responded to the first and second invitation by the researcher, 10 institutions agreed to participate in current study. In the second stage, from each university which agreed to participate, a number of academic departments were chosen and they represented both the hard sciences and the social sciences. In the final stage, academics who served as respondents were selected randomly. A total of 400 sets of questionnaires were distributed directly to the academics, 40 in each university of which 204 were completed and used for analysis.

Five-point Likert scale was applied to measure the respondent's perceived level of importance and implementation of internationalization attributes (total of 31 attributes) at their institution. This scale was found to be commonly used by researchers in measuring knowledge management practices (Chong, 2007). The five-point importance scale starts at 1 as 'not important', 2 as 'minor important', 3 as 'moderately important', 4 as 'important' and 5 as 'highly important'. The five-point implementation scale starts at 1 as 'not implemented', 2 as 'little implemented', 3 as 'moderately implemented', 4 as 'implemented' and 5 as 'extensively implemented'.

In terms of data analysis methods used to analyze the data obtained through the survey, descriptive and factor analysis were the major approaches. The descriptive findings include individual profiling, institutional profiling and perceived importance and perceived implementation of internationalization factors. Factor analysis was conducted to identify the separate dimensions of the structure, and then determine the extent to which each variable is explained by the various dimensions (Coakes and Steed, 2007; Chua, 2009).

Factor analysis has been regarded as one of the most powerful methods to test construct validity (Kerlinger, 1986 cited in Khoo, 2006). Thus, factor analysis was conducted and the percentage of the total variance explained for perceived importance: preliminary factor was $75.56 \%$, strategy factor was $79.88 \%$ and internationalization process was $77.47 \%$. The percentage of the total variance explained for perceived implementation: preliminary factor was $75.58 \%$, strategy factor was $74.84 \%$ and internationalization process was $71.36 \%$. The most common test for inter item consistency is the Cronbach's Alpha which is appropriate for a multi point scaled item (Richardson et al, 2005) and regarded as the most commonly used for estimating the reliability of a measure. An alpha coefficient above 0.7 signifies a high reliability (Chua, 2009). The Cronbach Alpha estimated for perceived 
importance: government policy (0.91), institutional policy and structure (0.837), leadership and governance (0.926), organizational support (0.939), human resources $(0.870)$ and technology integration (0.943). The Cronbach Alpha estimated for perceived implementation: government policy $(0.932)$, institutional policy and structure (0.82), leadership and governance (0.904), organizational support (0.898), human resources $(0.811)$ and technology integration (0.903). The value of Cronbach Alpha were all higher than 0.7, the constructs were therefore deemed to have adequate reliability.

\section{Results and discussion}

As shown in Table 1, the respondents equally represent the two gender groups consisting of males (51\%) and females (49\%). In the context of years of working experience with respective institutions, the highest group of respondents is those with 3 - 4 years of working experience. Nearly $32 \%$ of respondents have between $5-6$ years experience followed by $13 \%$ for $7-8$ years. A low $10 \%$ of the respondents have been working with their respective institution for more than 9 years. Approximately 16 percent of the respondents are Professors followed by 19 percent from the group consisting of deans, assistant or deputy deans and heads of department. The majority of the respondents are senior lecturers $(21.1 \%)$ and lecturers $(44.1 \%)$. As for academic qualification, respondents with master's degree constituted $67.6 \%$ while the rest were with a PhD qualification $(32.4 \%)$. It was found that the respondents with the above qualifications represented the major two fields of study comprising the hard sciences (44.6\%) and the social sciences $(55.4 \%)$.

In order to analyze the perceived importance and implementation of internationalization, descriptive statistics for 3 groups of internationalization elements (preliminary factors, strategy factors and process factors) were calculated. The descriptive aggregate data in terms of mean, standard deviation and group mean scores for preliminary factors, strategies and processes are shown in Table 2, 3 and 4 respectively.

As indicated in Table 2, the respondents view government policy as the most critical factor towards internationalization $(\mathrm{m}=4.22)$ compared to institutional policy and structure $(\mathrm{m}=4.02)$. On the implementation side, government policy scored slightly higher $(\mathrm{m}=3.4)$ compared to institutional policy and structure $(\mathrm{m}=3.23)$. These preliminary factors are perceived as highly important, but when it comes to implementation, the perceived level is moderate.

As shown in Table 3, there are four constructs and eighteen attributes or items with their mean and standard deviation values respectively. The respondents view technology integration, leadership and governance, and organizational support as the most important factors with mean values of $4.35,4.18$ and 4.01 respectively followed by human resource with 3.95 which is slightly lower than the above mean values. As shown in Table 3 , on the implementation side, the mean values of all four factors are lower compared to those under importance. The respondents view implementation of technology integration $(\mathrm{m}=3.61)$ and leadership cum governance $(m=3.42)$ higher compared to organizational support $(m=2.96)$ and human resources $(m=2.86)$. Thus, it can be concluded that the four factors of internationalization strategies are perceived highly as important, but the implementation of these factors are between the lower (organizational support and human resources) and moderate stage (technology integration and leadership and governance).

As indicated in Table 4, the respondents' perception on both international ethos and innovativeness are obviously higher in terms of the degree of importance compared to the degree of implementation. As for perceived importance, the mean scores for the above factors are 4.24 and 4.12 respectively. This narrow gap indicates that the respondents view international ethos and innovativeness as equally important under the internationalization process. As for perceived implementation, both factors of internationalization process highlighted above scored 3.66 and 3.03 respectively. Thus, it can be concluded that internationalization processes constituting international ethos and innovativeness are perceived as highly important, but implementation of these factors are moderate.

As a conclusion for the descriptive analysis above, Table 5 shows an overview of all the factors associated with the importance and implementation perspectives in order to compare the mean value of the individual factor with the overall mean value for the independent variables. As indicated in Table 5, the average mean values of factors from the importance perspective is 4.14 which is higher than 3.27 , the value accounted for the degree of implementation. In terms of perceived importance, there are four factors which scored above the average mean values of all factors (4.14). These are government policy, leadership and governance, technology integration, and international ethos. As for perceived implementation, although the individual scores are lower compared with those under importance, but within the implementation domain, they scored above the average mean values of all factors (3.27). Factors that scored below the average mean values of all factors under both the importance and implementation perspectives are institutional policy, organization support, human resources and innovativeness respectively. 


\section{Conclusion}

Throughout this study, various internationalization approaches were integrated and analyzed in order to gain the description and understanding of the extent of importance perceived versus implementation of internationalization dimensions by respondents' institutions. Based on an overview of all dimensions and attributes, the perceived degree of importance is higher than the perceived degree of implementation of internationalization by academics at Malaysian private universities. Government policy, leadership and governance, technology integration, and international ethos are among the factors scored above the average mean values of all factors from both perceived importance and implementation perspectives. Factors that scored below the average mean values of all factors from both perceived importance and implementation perspectives are institutional policy, organization support, human resources and innovativeness respectively. The overall finding reflects the private universities in Malaysia as all other universities around the world recognize internationalization policies, strategies and processes. However, the perceived implementation levels indicates that the private universities still have long way to go in grasping the international standards which is possible by ensuring their status as a 'university' is comparable with other universities in Malaysia and also other countries. This means, the internationalization practitioners are recommended to integrate the international dimension on all three core activities of a university, namely, teaching, research and services. Besides focusing on foreign students and staffs recruitment (international ethos), strategies on organizational support and human resource cum recognition as well as innovativeness as a process are also equally important in ensuring the institution's sustainability and competitiveness in international marketplace. This direction, in long term, may drive them to strive towards a progressive and successful internationalization in order to reach international academic standards.

This study extends the scope of the internationalization literature on an emerging market context and probably one of the first to conduct empirical tests/structured questionnaire in assessing internationalization issues in the context of the Malaysian private university sector. The study traced internationalization efforts of Malaysian private universities which provide practitioners with more evidence of the value of internationalization. The conceptual framework exemplified in this study is considered the most significant contribution of this research work in terms of providing measurement tools for evaluation and assessment of internationalization efforts in the higher education domain. However, the study was carried out using a moderate sample size which is due to the fact that only 10 Malaysian private universities agreed to contribute or participate in this study.

\section{References}

Ahmad Saat. (2007). Internationalization of Higher Education: Preparation, Policy, Implementation and Recognition. Paper presented at the INCUE07, Shah Alam, Malaysia. [Online] Available: http://myais.fsktm.um.edu.my/3064/

Akiba, H. (2008). The Changing Face of Transnational Education in Malaysia: A Case Study of International Offshore University Programs. Doctoral dissertation, University of Minnesota.

Altbach, P. G., \& Knight, J. (2006). The Internationalization of Higher Education: Motivations and Realities. The NEA Almanac of Higher Education.

Andersson, S. (2004). Internationalization in different industrial contexts. Journal of Business Venturing. 19, 851-875. http://dx.doi.org/10.1016/j.jbusvent.2003.10.002

Ayoubi, R. M., \& Massoud, H. K. (2007). The strategy of internationalization in Universities: A quantitative evaluation of the intent and implementation in UK universities. International Journal of Educational Management, 21(4), 329-349. http://dx.doi.org/10.1108/09513540710749546

Bartell, M. (2003). Internationalization of universities: A university culture-based framework. Higher Education, 45, 43-70. http://dx.doi.org/10.1023/A:1021225514599

Bendriss, R. (2007). Internationalization Efforts at State Universities in Florida (Doctoral dissertation, University of Central Florida, 2007).

Bentkowska, K. (2007). Knowledge as a factor of international expansion of enterprises. France: 16th EDAMBA Summer School Academy.

Birnbaum, R. (2007). No World-Class University Left Behind. International higher education of quarterly publication, 47(spring). The Boston College: CIHE. [Online] Available: http://www.bc.edu/bc_org/avp/soe/cihe/newsletter/Number47/p7_Birnbaum.htm

Bourke, A. (2000). A Model of the Determinants of International Trade in Higher Education. The Service 
Industries Journal, 20(1), 110-138. http://dx.doi.org/10.1080/02642060000000007

Brennan, L., \& Garvey, D. (2009). The role of knowledge in internationalization. Research in International Business and Finance, 23, 120-133. http://dx.doi.org/10.1016/j.ribaf.2008.03.007

Casillas, J. C., Moreno, A. M., Acedo, F. J., Gallego, M. A., \& Ramos, E. (2008). An integrative model of the role of knowledge in the internationalization process. Journal of World Business. Article in press, http://dx.doi.org/10.1016/j.jwb.2008.08.001

Chan, W. W. Y., \& Dimmock, C. (2008). The Internationalization of universities: Globalist, internationalist and translocalist models. Journal of Research in International Education, 7(2), 184-204. http://dx.doi.org/10.1177/1475240908091304

Childress, L. K. (2009). Internationalization Plans for Higher Education Institutions. Journal of Studies in International Education, OnlineFirst, 1-21. http://dx.doi.org/10.1177/1028315308329804.

Choi, J. G. (2003). The Internationalization of higher education: The case of Korean universities. Doctoral dissertation, The Catholic University of America.

Chong, C. W. (2007). Knowledge Management Implementation in the Malaysian telecommunication Industry: An Empirical Evaluation. Doctoral Dissertation, Multimedia University.

Chua, Y. P. (2009). Advanced Statistical Analysis: Regression Test, Factor Analysis and SEM Analysis. Malaysia: McGraw-Hill.

Coakes, S. J., \& Steed, L. (2007). SPSS Version 14.0 for Windows: Analysis without Anguish. Australia: John Wiley \& Sons, Ltd.

Courts, A. D. (2004). Internationalizing an Institution: An emerging model of effective leadership, infrastructure and cultural factors7. Doctoral dissertation, West Virginia University.

Dewey, P., \& Duff, S. (2009). Reason before passion: faculty views on internationalization in higher education. Springer: Higher Educ, 58, 491-504.

Elango, B. (1998). An empirical examination of the influence of industry and firm drivers on the rate of internationalization by firms. Journal of International Management, 4, 201-221. http://dx.doi.org/10.1016/S1075-4253(98)00011-8

Enders, J. (2004). Higher Education, internationalization, and the nation-state: recent developments and challenges to governance theory. Higher Education, 47, 361-382. http://dx.doi.org/10.1023/B:HIGH.0000016461.98676.30

Fielden, J. (1996). Is Internationalization Manageable? Commonwealth Higher Education Service (CHEMS). Paper No. 23.

Ghauri, P., \& Grounhaug, K. (2005). Research Methods in Business Studies: A Practical Guide. UK: Pearson Education Limited.

Hair, J. F., Black, W. C., Babin, B. J., Anderson, R. E., \& Tatham, R. L. (2006). Multivariate Data Analysis. USA: Pearson Prentice Hall

Horn, A. S., Hendel, D. D., \& Fry, G. W. (2007). Ranking the international dimension of top Research Universities in the United States. Journal of Studies in International Education, 11, 330-358. http://dx.doi.org/10.1177/1028315306294630

Horta, H. (2009). Global and national prominent universities: internationalization, competitiveness and the role of the State. Springer: Higher Educ, 58, 387-405.

International Association of Universities. (2003). Internationalization of Higher Education: Practices and Priorities: 2003 IAU Survey Report. [Online] Available: http://www.unesco.org/iau/internationalization/pdf/Internationalisation-en.pdf

International Association of Universities (2005). IAU 2005 Internationalization Survey: Preliminary findings report. Paris: France.

Irene, T. A. L. (2003). Internationalizing Higher Education: A Case Study of a Midwest Comprehensive University. Doctoral dissertation, University of Northern Iowa.

Jang, J. (2009). Analysis of the Relationship between Internationalization and the Quality of Higher Education. Doctoral Dissertation, University of Minnesota. 
Kafouros, M. I., Buckley, P. J., Sharp, J. A., \& Wang, C. (2008). The role of internationalization in explaining innovation performance. Technovation, 28, 63-74. http://dx.doi.org/10.1016/j.technovation.2007.07.009

Khoo, A. C. (2006). Online Collaboration Learning for Malaysia Secondary Schools: A Case Study on Geometry. Doctoral Dissertation, Multimedia University.

Knight, J. (2003). Update Definition of Internationalization. International Higher Education of quarterly publication, 33, 2-3, The Boston College: CIHE. [Online] Available: http://www.bc.edu/bc_org/avp/soe/cihe/newsletter

Knight, J. (2004). Internationalization remodeled: Definition, approaches, and rationales. Journal of Studies in International Education, 8, 5-31. http://dx.doi.org/10.1177/1028315303260832

Knight, J. (2004). New Rationales Driving Internationalization. International Higher Education of quarterly publication, 34, 3-5. The Boston College: CIHE. [Online] Available: http://www.bc.edu/bc_org/avp/soe/cihe/newsletter

Knight, J. (2006). Higher education crossing borders: A guide to the implications of the general agreement on trade in services (GATS) for cross-border education. A report prepared for the Commonwealth of Learning and UNESCO, France: COL/UNESCO.

Lee, M. N. N. (2000). International Linkages in Malaysian Private Higher Education. The Boston College Center for International Higher Education. [Online] Available: http://www.bc.edu/bc_org/avp/soe/cihe/newsletter/News30/text009.htm

Malaysian Business: Supplement Edition, News Straits Times Press. (2003, January 16). Private Education Steaming Ahead. News Straits Times Press, pp. 2.

Manning, K. (1998, July). Internationalizing universities: A strategic framework. Paper presented at the $21^{\text {st }}$ Annual Conference, Auckland, New Zealand. [Online] Available: http://www.herdsa.org.au/wp-content/uploads/confrerence/1998/

Marginson, S. (2004). National and Global competition in higher education. The Australian Education Researcher, 31(2), 1-28.

Marginson, S. (2006, March). Notes on globalization and higher education: With some reference to the case of Australia. A Symposium on Internationalizing Canada's universities-Practices, challenges and opportunities, Toronto.

Ministry of Education Malaysia. (2004). The Development of Education (National Report of Malaysia). Malaysia.

Ministry of Higher Education Malaysia. (2004). Current update of higher education in Malaysia. Paper presented by Ahmad Nazri Sulaiman, Senior Principal Assistant Director, Ministry of Higher Education, Malaysia.

Ministry of Higher Education. (2007). National higher education action plan: 2007-2010. Malaysia: Putrajaya.

Ministry of Higher Education. (2007). Statistics on Private Higher Education Institution in Malaysia. [Online] Available: www.mohe.gov.my

Mohayidin, M. G. (2007). The Application of Knowledge Management in Enhancing the Performance of Malaysian Universities. The Electronic Journal of Knowledge Management, 5(3), 301-312. [Online] Available: www.ejkm.com

Mok, K. H. (2007). Questing for Internationalization of universities in Asia: Critical reflections. Journal of Studies in International Education, 11, 433-454. http://dx.doi.org/10.1177/1028315306291945

Morshidi Sirat \& Kaur, S. (2007). The Internationalisation of Higher Educations: Realities and Implications. Institut Penyelidikan Pendidikan Tinggi Negara: Updates on Global Higher Education. No.14.

Navarro, M. (2004). Analysis of Factors Affecting Participation of Faculty and Choice of Strategies for the Internationalization of the Undergraduate Agricultural Curriculum: The Case in Two Land Grant Universities. Doctoral Dissertation, Texas A\&M University.

Nelson, J. M. (2007). Fast-Growing Nations, Globalization and Social Policy. Malaysia: Penerbit Universiti Kebangsaan Malaysia.

OECD. (2004). Internationalization and Trade in Higher Education: Opportunities and challenges. In Marginson $\mathrm{S} \& \mathrm{McBurnie} \mathrm{G}$ (Authors) Cross-border post-secondary education in the Asia-Pacific region, pp. 137-204. 
OECD. (2004). Internationalization of higher education. Policy brief. [Online] Available: www.oecd.org/publications/Pol_brief

Kalaivani Radakrishnan., \& Santhi Ramanathan. (2010). ICT as a success factor of internationalization in higher education: A study on Malaysian Private Universities. Ubiquitous Learning: An International Journal, 2(2), 15-28.

Santhi Ramanathan., \& Halima Awang. (2009). Exploring the Readiness of Malaysian Private Universities towards World-Class University. Proceedings from 12th International Business Information Management Conference. Kuala Lumpur: Malaysia.

Santhi Ramanathan., \& Murali Raman. (2009). Globalizing Malaysian Private Higher Education: An Exploratory Perspective. Journal of the World Universities Forum, 2(6), 49-65.

Reedstrom, A. (2005). Dickinson College meets the world: The integration of internationalization into institutional culture. Doctoral dissertation, University of Pennsylvania.

Richardson, S., Balachander, K., Cheng, M. Y., Chew, K. W., \& Pointon, L. (2005). How to Research: A Guide for Undergraduate \& Graduate Students. Singapore: Thomson Learning.

Sivalingam, G. (2006). Privatization of higher education in Malaysia. The Forum on Public Policy, 1-27.

Sun, Yunpeng. (2005). Internationalization of Higher Education in China: From a Historical Perspective. Dissertation, Memorial University of Newfoundland.

Tan, A. M. (2002). Malaysian Private higher Education: Globalization, Privatization, Transformation \& Marketplaces. [Online] Available: http://www.studymalaysia.com

Tham, S. Y., \& Kam, A. J. Y. (2008). Internationalising higher education: comparing the challenges of different higher education institutions in Malaysia. Asia Pacific Journal of Education, 28(4), 353-367. http://dx.doi.org/10.1080/02188790802468880

The Star Education. (2008, June 8). Big plans afoot. The Star, pp.10.

The Star Online. (2008, June 8). Doing it his way, with team support. [Online] Available: http://www.thestar.com.my

Thune, T., \& Welle-Strand, A. (2005). ICT for and in internationalization processes: A business school case study. Higher Education, 50, 593-611. http://dx.doi.org/10.1007/s10734-004-6368-7

Tuppura, A., Saarenketo, S., Puumalainen, K., Jantunen, A., \& Kylaheiko, K. (2008). Linking knowledge, entry timing and internationalization strategy. International Business Review, 17, 473-487. http://dx.doi.org/10.1016/j.ibusrev.2008.02.003

UNESCO \& SEAMEO RIHED. (2006). Higher Education in South-East Asia. In Morshidi S (Author) Malaysia, (pp. 101-136). Thailand: UNESCO Asia and Pacific Regional Bureau for Education.

UNESCO (1995). Private Higher Education in Asia and the Pacific. In Nuraizah AH (Author) Private Higher Education in Malaysia: Current development and future direction, pp.73-82. Thailand: UNESCO.

UNESCO (2005). Implications of WTO/GATS on higher education in Asia and the Pacific region. In Knight J (Authors) Cross-border education: Developments and implications in Asia-Pacific. UNESCO Forum Occasional Paper Series, No. 8, pp. 20-79, Seoul, Korea.

UNESCO (2005). The Implication of WTO/GATS on higher education in Asia \& the Pacific. In Gill SK (Author) The Implication of WTO/GATS on higher education in Malaysia. UNESCO Forum Occasional Paper Series, No. 9, pp. 86-113, Seoul, Korea.

UNESCO Asia and Pacific Regional Bureau for Education (2003). Higher Education in Asia and the Pacific 1998-2003. Regional report on progress in implementing recommendations of the 1998 World Conference on Higher Education. Paris: UNESCO.

Wang, C., Hsu, L., \& Fang, S. (2008). The determinants of internationalization: Evidence from the Taiwan high technology industry. Technological Forecasting \& Social Change. 75, 1388-1395. http://dx.doi.org/10.1016/j.techfore.2008.03.002

Weerawardena, J., Mort, G. S., Liesch, P. W., \& Knight, G. (2007). Conceptualizing accelerated internationalization in the born global firm: A dynamic capabilities perspective. Journal of World Business, 42, 294-306. http://dx.doi.org/10.1016/j.jwb.2007.04.004 
Welch, A. (1997). The peripatetic professor: the internationalization of the academic profession. Higher Education, 34, 323-345. http://dx.doi.org/10.1023/A:1003071806217

Welle-Strand, A. (2002). Internationalisation and ICT in a Service University. Paper from $7^{\text {th }}$ Quality in Higher Education International Seminar, Australia. [Online] Available: http://www.qualityresearchinternational.com/tq/papers/well-strand.doc.

World Bank. (2007). Malaysia and the Knowledge Economy: Building a world-class higher education system. The World Bank: Human Development Sector Reports, East Asia and the Pacific Region.

Yonezawa, A. (2007). Strategies for the Emerging Global Higher Education Market in East Asia: A Comparative Study of Singapore, Malaysia and Japan. Globalization, Societies and Education, 5(1), 125-136. http://dx.doi.org/10.1080/14767720601133561

Zeng, S., Xie, X. M., Tam, C. M., \& Wan, T. W. (2009). Relationships between business factors and performance in internationalization: An empirical study in China. Management Decision, 47(2), 308-329. http://dx.doi.org/10.1108/00251740910938939

Zha, Q. (2003). Internationalization of Higher Education: towards a conceptual framework. Policy Futures in Education, 1(2), 248-270. http://dx.doi.org/10.2304/pfie.2003.1.2.5

Ziguras, C. (2001, December). The Effect of GATS on Transnational Higher Education: Comparing Experiences of New Zealand, Australia, Singapore and Malaysia. Paper presented at the Australia Association for Research in Education Annual Conference, Fremantle WA, Australia.

[Online] Available: www.studymalaysia.com

[Online] Available: www.mohe.gov.my

[Online] Available: www.wto.org

Table 1. The profiles of respondents

\begin{tabular}{|l|l|c|}
\hline Demographic & Demographic details & Percentage (\%) \\
\hline Gender & Male & 51 \\
& Female & 49 \\
\hline Length of service (years) & $3-4$ years & 45.1 \\
& $5-6$ years & 31.9 \\
& $7-8$ years & 13.2 \\
& $\geq 9$ years & 9.8 \\
\hline Job category & Professor/Assistant Professor/Associate Professor & 15.7 \\
& Dean/Deputy/Assistant Dean & 4.9 \\
& Head of department & 14.2 \\
& Senior lecturer & 21.1 \\
\hline Qualification & Lecturer & 44.1 \\
\hline Department & Masters Degree & 67.6 \\
& PhD & 32.4 \\
\hline Respondent's knowledge & Hery poor & 44.6 \\
on internationalization in & Poor & 55.4 \\
the context of higher & Fair & 0 \\
education & Good & 0.5 \\
& Very good & 47.5 \\
\hline
\end{tabular}


Table 2. Construct and Items of Internationalization Preliminary Factors

\begin{tabular}{|c|c|c|c|c|}
\hline \multirow[b]{2}{*}{ Constructs and Items } & \multicolumn{2}{|c|}{$\begin{array}{l}\text { Perceived } \\
\text { Importance }\end{array}$} & \multicolumn{2}{|c|}{$\begin{array}{c}\text { Perceived } \\
\text { Implementation }\end{array}$} \\
\hline & $\stackrel{\text { है }}{\sum^{ \pm}}$ & 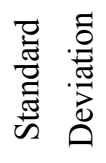 & $\sum_{\Sigma}^{\varpi ี}$ & 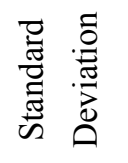 \\
\hline \multicolumn{5}{|l|}{ Institutional Policy and Structure } \\
\hline $\begin{array}{l}\text { Restructuring of institution efforts that are streamlined with } \\
\text { global needs \& expectation }\end{array}$ & 4.01 & 0.800 & 3.20 & 0.912 \\
\hline $\begin{array}{l}\text { Assuring programs offered are in accordance to Malaysian as } \\
\text { well as international higher education standards \& requirements }\end{array}$ & 4.27 & 0.709 & 3.54 & 0.873 \\
\hline A flexible structure which able to adapt to environmental change & 4.00 & 0.702 & 3.05 & 0.774 \\
\hline $\begin{array}{l}\text { Adhere to both centralized and decentralized methods of } \\
\text { decision making }\end{array}$ & 3.93 & 0.769 & 3.13 & 0.867 \\
\hline Group Mean Score & 4.05 & 0.7 & 3.23 & 0.9 \\
\hline \multicolumn{5}{|l|}{ Government Policy } \\
\hline $\begin{array}{l}\text { Government policy of encouraging the establishment of private } \\
\text { universities }\end{array}$ & 4.27 & 0.723 & 3.51 & 0.833 \\
\hline $\begin{array}{l}\text { Government policy of encouraging internationalization efforts } \\
\text { among private universities }\end{array}$ & 4.19 & 0.799 & 3.40 & 0.851 \\
\hline $\begin{array}{l}\text { Government policy of providing support \& opportunities for } \\
\text { private universities (grants/funds/tax exemption, etc.) }\end{array}$ & 4.20 & 0.866 & 3.29 & 0.958 \\
\hline Group Mean Score & 4.22 & 0.8 & 3.4 & 0.9 \\
\hline
\end{tabular}


Table 3. Constructs and Items of Internationalization Strategy Factors

\begin{tabular}{|c|c|c|c|c|}
\hline \multirow[b]{2}{*}{ Constructs and Items } & \multicolumn{2}{|c|}{$\begin{array}{l}\text { Perceived } \\
\text { Importance }\end{array}$} & \multicolumn{2}{|c|}{$\begin{array}{l}\text { Perceived } \\
\text { implementation }\end{array}$} \\
\hline & 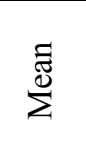 & 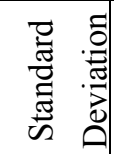 & 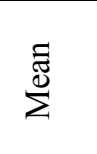 & 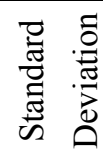 \\
\hline \multicolumn{5}{|l|}{ Leadership and Governance } \\
\hline $\begin{array}{l}\text { Top management creating awareness on institution's competitive position } \\
\text { internationally }\end{array}$ & 4.19 & 0.765 & 3.36 & 0.917 \\
\hline Top management leadership and commitment towards internationalization & 4.25 & 0.744 & 3.53 & 0.856 \\
\hline Mission statement which relates to the quest for internationalization & 4.12 & 0.729 & 3.37 & 0.869 \\
\hline Formulating strategic plans related to internationalization & 4.17 & 0.763 & 3.42 & 0.876 \\
\hline Group Mean Score & 4.18 & 0.8 & 3.42 & 0.9 \\
\hline \multicolumn{5}{|l|}{ Organizational Support } \\
\hline $\begin{array}{l}\text { Enhance faculty knowledge \& understanding on the internationalization } \\
\text { process }\end{array}$ & 3.91 & 0.783 & 2.84 & 0.946 \\
\hline $\begin{array}{l}\text { A specific department/division for coordinating internationalization } \\
\text { activities }\end{array}$ & 4.03 & 0.964 & 3.02 & 1.136 \\
\hline Skilled and experienced staff to lead \& guide internationalization efforts & 4.07 & 0.934 & 2.94 & 0.985 \\
\hline $\begin{array}{l}\text { Access to reliable \& comprehensive information on international events } \\
\text { and contacts }\end{array}$ & 3.97 & 0.850 & 2.92 & 0.989 \\
\hline $\begin{array}{l}\text { Access to internationalized teaching materials and library resources with } \\
\text { international references }\end{array}$ & 4.12 & 0.775 & 3.16 & 1.024 \\
\hline Budgeting and funding to support internationalization policy/strategy & 4.06 & 0.816 & 2.99 & 0.909 \\
\hline $\begin{array}{l}\text { Reformulation of financial practices that obstruct the internationalization } \\
\text { policy/strategy }\end{array}$ & 3.93 & 0.812 & 2.87 & 0.987 \\
\hline Group Mean Score & 4.01 & 0.8 & 2.96 & 1.00 \\
\hline \multicolumn{5}{|l|}{ Human Resources } \\
\hline $\begin{array}{l}\text { Sponsoring faculty to participate in international conferences \& } \\
\text { publication }\end{array}$ & 4.17 & 0.807 & 3.29 & 1.079 \\
\hline Release time from teaching for internationalization efforts & 3.81 & 1.016 & 2.74 & 1.067 \\
\hline $\begin{array}{l}\text { Rewarding faculty participation in internationalization efforts (salary } \\
\text { increases, promotion, etc.) }\end{array}$ & 3.86 & 1.060 & 2.58 & 1.152 \\
\hline Providing opportunities for faculty to study abroad & 3.94 & 0.976 & 2.83 & 1.145 \\
\hline Group Mean Score & 3.95 & 0.965 & 2.86 & 1.111 \\
\hline \multicolumn{5}{|l|}{ Technology Integration } \\
\hline Up-to-date Information and Communication Technologies (ICT) & 4.28 & 0.726 & 3.46 & 0.911 \\
\hline $\begin{array}{l}\text { Access to ICT in management \& administration (Internet, Intranet, email, } \\
\text { etc) }\end{array}$ & 4.40 & 0.662 & 3.76 & 0.852 \\
\hline \multirow[t]{2}{*}{$\begin{array}{l}\text { Access to ICT in teaching, learning \& research (Internet, Intranet, email, } \\
\text { video conferencing, etc) }\end{array}$} & 4.37 & 0.734 & 3.61 & 0.883 \\
\hline & 4.35 & 0.707 & 3.61 & 0.873 \\
\hline
\end{tabular}


Table 4. Constructs and Items of Internationalization Process Factors

\begin{tabular}{|c|c|c|c|c|}
\hline \multirow[b]{2}{*}{ Constructs and Items } & \multicolumn{2}{|c|}{$\begin{array}{c}\text { Perceived } \\
\text { Importance }\end{array}$} & \multicolumn{2}{|c|}{$\begin{array}{c}\text { Perceived } \\
\text { implementation }\end{array}$} \\
\hline & $\sum_{\Sigma}^{\Xi}$ & 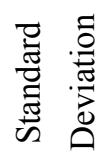 & 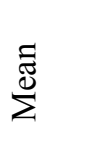 & 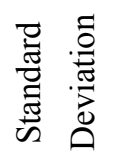 \\
\hline \multicolumn{5}{|l|}{ International Ethos } \\
\hline $\begin{array}{l}\text { Acceptance of faculty employment from various foreign } \\
\text { institutions of higher learning }\end{array}$ & 4.10 & 0.763 & 3.30 & 1.052 \\
\hline Welcomes the enrollment of students from all over the world & 4.39 & 0.646 & 4.02 & 0.821 \\
\hline Group Mean Score & 4.24 & 0.7 & 3.66 & 0.9 \\
\hline \multicolumn{5}{|l|}{ Innovativeness } \\
\hline $\begin{array}{l}\text { Creating opportunities \& linkages for students to engage in } \\
\text { international and inter-cultural curricular activities }\end{array}$ & 4.11 & 0.805 & 3.19 & 1.071 \\
\hline $\begin{array}{l}\text { Collaborate with foreign partners or universities through } \\
\text { e-learning or distance education }\end{array}$ & 4.11 & 0.814 & 3.13 & 1.080 \\
\hline $\begin{array}{l}\text { Engage in joint-research projects with foreign partners or } \\
\text { universities }\end{array}$ & 4.13 & 0.890 & 3.00 & 0.995 \\
\hline \multirow[t]{2}{*}{$\begin{array}{l}\text { Co-organize international symposia or conference with } \\
\text { foreign partners or universities }\end{array}$} & 4.12 & 0.874 & 2.80 & 1.212 \\
\hline & 4.12 & 0.8 & 3.03 & 1.1 \\
\hline
\end{tabular}

Table 5. Mean Scores for Internationalization Factors

\begin{tabular}{|c|c|c|c|c|}
\hline \multirow[b]{2}{*}{ Factor } & \multicolumn{2}{|c|}{$\begin{array}{c}\text { Perceived } \\
\text { Importance }\end{array}$} & \multicolumn{2}{|c|}{$\begin{array}{c}\text { Perceived } \\
\text { implementation }\end{array}$} \\
\hline & 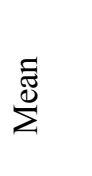 & 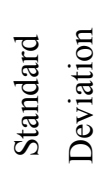 & $\sum_{\Sigma}^{\mathbb{E}}$ & 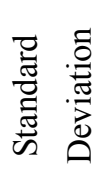 \\
\hline 1. Institutional Policy & 4.05 & 0.7 & 3.23 & 0.9 \\
\hline 2. Government Policy & 4.22 & 0.8 & 3.40 & 0.9 \\
\hline 3. Leadership and Governance & 4.18 & 0.8 & 3.42 & 0.9 \\
\hline 4. Organizational Support & 4.01 & 0.8 & 2.96 & 1.00 \\
\hline 5. Human Resources & 3.95 & 0.97 & 2.86 & 1.11 \\
\hline 6. Technology Integration & 4.35 & 0.71 & 3.61 & 0.87 \\
\hline 7. International Ethos & 4.24 & 0.70 & 3.66 & 0.9 \\
\hline 8. Innovativeness & 4.12 & 0.8 & 3.03 & 1.1 \\
\hline Average Mean Score of Factor & 4.14 & 0.8 & 3.27 & 0.96 \\
\hline
\end{tabular}


Highly important

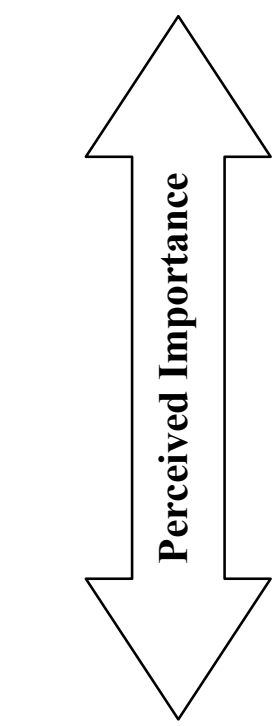

Not important

\begin{tabular}{|c|}
\hline Internationalization factors \\
Preliminary Factors \\
Institutional Policy and Structure \\
Government Policy \\
Strategy Factors \\
Leadership \& Governance \\
Organizational Support \\
Human Resources \\
Technology integration \\
Internationalization Process \\
International Ethos \\
Innovativeness \\
\hline Internationalization factors
\end{tabular}

Extensively implemented

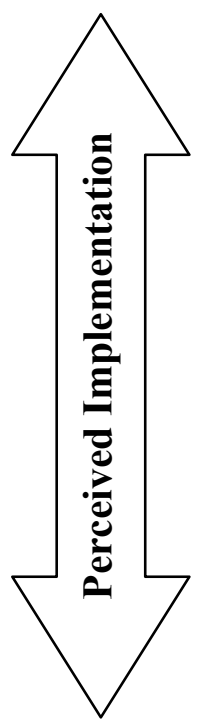

Not implemented

Figure 1. Conceptual framework 